\title{
IFRS for Insurance: CFO Forum Proposals
}

\author{
Denis Duverne and Jacques Le Douit \\ AXA, Avenue Matignon 25, Paris 75008, France. \\ E-mail: denis.duverne@axa.com
}

European insurers who have to establish financial statements under IFRS must apply a temporary international accounting standard for insurance contracts which provides a flawed picture of their business. The IFRS long-term project for insurance is still under preparation by the IASB. The standard should not be issued until mid-2009 following a discussion paper to be submitted for comments in the first quarter 2007. The insurance industry has been involved for several years in a proactive way, including participation in the International Insurance Working group set up by the IASB. The European CFO Forum has proposed principles on which the international accounting standard for insurance should be based. The key elements are as follows: the insurance liabilities should be valued on a market consistent measurement including the management's best estimate of future cash flows discounted at a risk-free rate and a margin for risks and uncertainties; the profit should be recognized as the insurer is released from risks, and services are provided to the policyholders over the term of contracts and not at inception. Participating contracts liabilities should be based on an economic valuation. Liabilities should be reassessed at each closing. If applied, the CFO Forum's principles would have positive impacts for the investors and other users of the financial statements while entailing huge operational implications. The proposals from the European industry for accounting are closely linked to the proposals for Solvency II that the European Commission is preparing in the meantime: the measurement of the insurance liabilities proposed for both purposes by the CFO Forum, the CRO Forum and the CEA is the same. The American insurers members of the GNAIE and four Japanese Life Insurance groups have made similar propositions for accounting but with some differences that are under debate with the CFO Forum. The Geneva Papers (2007) 32, 62-74. doi:10.1057/palgrave.gpp.2510121

Keywords: best estimate liabilities (BEL); current exit/entry value; market consistent; (no) profit at inception; unlocking of assumptions; risk service/profit margin

\section{Where are we?}

\section{IASB Phase II project}

The IASB ${ }^{1}$ (and previously its predecessor the IASC) has been working for several years on a project of a standard for the insurance sector. As a first stage, considering the absence of a specific standard for insurance contracts and following the recommendation of the industry, the IASB in May 2003 decided to split this project into two phases.

\footnotetext{
${ }^{1}$ International Accounting Standard Board, a private body that sets accounting standards for international financial reporting (IAS and IFRS).
} 


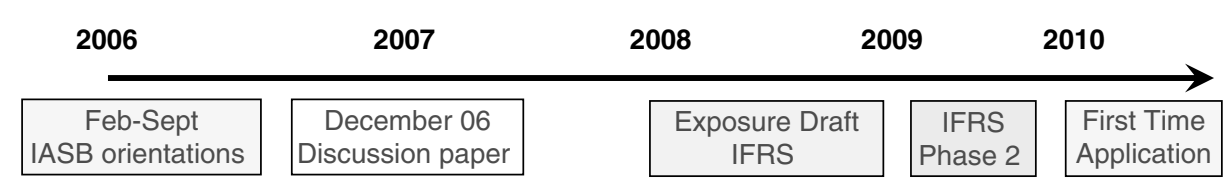

Figure 1. Timetable for IFRS Phase II.

The objective of Phase I was to allow the European listed insurance companies to comply with the European regulation and to establish their consolidated financial statements under IFRS for the periods starting in 2005. The Board completed Phase I in March 2004 by issuing an interim standard: IFRS 4 Insurance Contracts.

Phase II aims at issuing the final long-term IFRS for insurance contracts. The first step of this second phase has mainly consisted of discussions by the Board during its monthly meetings held from February to October 2006 when the Board took its tentative orientations; this step is expected to be completed during the first quarter of 2007, when a discussion paper is to be released.

After public release of the discussion paper and a period for comments, the Board will then start its deliberations again; an exposure draft would be expected within 18 months (mid-2008) and the final standard within another 12 months (mid-2009) for a first application not expected before 2011 (see Figure 1).

\section{Convergence between IASB and FASB}

The insurance project of IASB is not included in the memorandum of understanding (MoU) for convergence between the IASB and its American counterpart, the U.S. Financial Accounting Standard Board (FASB). However, the IASB expects that this will be a "modified joint" project. In other words, the FASB plans to issue an "Invitation to Comment" containing the IASB discussion paper in parallel to publication by IASB. The FASB will consider the responses in deciding whether to add to its agenda a joint project with the IASB to develop a comprehensive standard on accounting for insurance contracts.

This has two major consequences: (i) the strong involvement of the U.S. industry in the debate between the insurers and the IASB; and (ii) were the FASB to decide to be a party to this project, some additional delay would be likely.

\section{Summary of IASB tentative conclusions up to July 2006}

The single model proposed by the IASB for life insurance and for property and casualty insurance is a prospective measurement of the insurance liabilities based on:

- projected future cash flows (current unbiased probability-weighted estimates);

- discounted at current market discount rate, excluding any factors that influence the observed rate but are not relevant to the liability (e.g., risks present in the instrument used as a benchmark but not present in the liability);

- including a margin that market participants require for bearing risk (a risk margin) and for providing other services, if any (a service margin).

This approach, defined as a "current exit value" (transfer to another insurer at market conditions or business to business "B to B" model), would allow possible recognition 
of gain at inception. It has been tentatively adopted at a very low majority of seven Board members against six and one abstention. The Board has rejected the "current entry value" (business to customer "B to C" model) with no profit at inception.

These decisions show that the board is still hesitating on recognition of up-front profit:

- the "current exit value" would include the profit margin required by the market participants;

- consequently, the profit at inception should be limited to the actual amount of profit margin in the premium in excess of the profit margin charged by reference market participants if any (practically in most cases no profit at inception).

Among other orientations, the IASB has considered some specific topics:

Policyholder relationship and acquisition costs:

- The policyholders must make future payments to retain the right to guaranteed insurability. The corresponding insurer's right should be recognized as an asset (customer relationship).

- Acquisition costs should be expensed but acquisition costs might be a proxy for estimating the customer relationship.

Participating contracts:

- Expected policyholder participation rights should not be recognized as a liability (but as retained earnings) until the insurer has an unconditional obligation (in a "legal" approach: when the participation is declared?) to transfer economic benefits to policyholders, current or future, i.e., the insurer has an enforceable obligation: an obligation may be enforceable in various ways, including legal action or intervention by a regulator. However, economic compulsion is not sufficient to create an enforceable obligation.

- Only if an unconditional obligation comes into existence subsequently, then the insurer should recognize the resulting liability and an expense at that time.

\section{Unbundling}

An insurer should unbundle insurance deposit and service components of insurance contracts except if the components are so interdependent that the components can be measured only on an arbitrary basis.

The traditional historic cost model has been rejected by the IASB for insurance liabilities as well as for assets. Financial assets held by insurance companies must be measured at fair value in most cases. The IASB has refused to create any specific category of assets backing insurance liabilities that could be valued at cost.

\section{Industry involvement and propositions}

Insurance Working Group (IWG) of the IASB: an informal, frustrating consultation process The IASB formed in mid-2004 an Insurance Working Group (IWG), made up of senior financial executives, analysts, actuaries, auditors and regulators. The IWG's 
role is to advise the IASB on the project but not to participate in the elaboration process of the standard.

After eight two-day meetings, held between September 2004 and June 2006, the outcome of the IWG is difficult to evaluate. The IASB members who attended the IWG meetings have listened to the IWG members but most propositions and arguments expressed have not been taken into consideration by the IASB. Indeed, the IASB members gave the impression that they considered only those that were consistent with their conceptual and theoretical framework rather than search to assess the economic picture of the insurance business. The minutes of the meeting were quite poor and failed to reflect the consensus which, quite often, emerged from the discussion between auditors, actuaries and preparers.

\section{CFO forum}

The CFO Forum which was created in 2002 is a high-level discussion group formed and attended by the Chief Financial Officers of major European insurance companies. ${ }^{2}$ Its aim is to discuss issues relating to financial reporting developments for their businesses and how they can create greater transparency for investors. The CEA and The Geneva Association have been associated to the CFO Forum since its creation.

The CFO Forum pursues the harmonization of financials and ultimately seeks to enhance stability, consistency and transparency for investors.

With regard to the IFRS Phase II project, the CFO Forum's objective is to provide timely and constructive input into the IASB process from the perspective of a significant group of preparers of financial statements.

As a major step before the IASB completes the preparation of its discussion paper by the end of 2006, the CFO Forum published in June 2006 "Elaborated Principles and Basis for Conclusions" following the "Principles for an IFRS Phase II Insurance Model" issued in July 2005 at a first stage. The CEA has supported the CFO Forum proposals and participated in the launch event in Brussels in June.

Insurance companies from around Europe had never come together directly to achieve a common objective in the accounting framework in this way before.

\section{GNAIE and Japanese life insurers}

The GNAIE $^{3}$ and some Japanese life insurers ${ }^{4}$ have undertaken similar action and issued proposals: "Principles for Accounting for Insurance Contracts" issued in July 2005, then "Extended principles for Life insurance" released in April 2006 and "Extended Principles for Non-Life Insurance" in June 2006.

\footnotetext{
${ }^{2}$ AEGON, Allianz, Aviva, AXA, BNP Paribas Assurances, CNP, Fortis, Generali, Hannover Re, ING, Legal \& General Group, Mapfre, Munich Re, Old Mutual, Prudential, Scottish Widows, Standard Life, Swiss Life, Swiss Re, Zurich Financial Services.

${ }^{3}$ GNAIE, Group of North American Insurance Enterprises: ACE Ltd.; AIG, Inc.; The Allstate and XL Capital, Ltd. Corporation; GE Insurance Solutions; General Reinsurance; Genworth Financial, Inc; The Hartford; Metropolitan Life Insurance Company; New York Life Insurance Company; Prudential Financial, Inc.

${ }^{4}$ Japanese life insurance companies are: Nippon Life Insurance Company, Dai-Ichi Life Insurance Company; Meiji Yasuda Life Insurance Company and Sumitomo Life Insurance Company.
} 
A coordination and exchange of views between the CFO Forum, GNAIE and Japanese Life Insurers has been organized directly between CFO members of the IASB Insurance Working Group and through a "Tripartite working group" on Phase II.

\section{CRO Forum, CEA and Solvency II}

The European industry is fully committed to providing constructive inputs to the European bodies responsible for the regulation and supervision of insurance activities.

- Together CEA and CRO Forum ${ }^{5}$ have made proposals for Solvency II Pillar 1 liabilities measurement;

- CFO Forum proposals for measurement of insurance liabilities for accounting and CEA-CRO Forum proposals for measurement of insurance liabilities for Solvency II are in the process of being reconciled.

\section{Key CFO Forum elaborated principles}

The CFO Forum proposes that a single model be used for life and for property and casualty insurance. This model is designed to reflect the reality of the insurance business. The insurer provides a service, mainly mitigation of risks, over the term of contracts; its cash flows are subject to uncertainty both due to the nature of risks and their timing:

- Profit must be recognized as the insurer is released from risks and as services are provided to policyholders.

- Nil gain or loss may be recognized at inception except if economic loss (liability adequacy test).

The measurement of the insurance liabilities has to reflect how the risk is managed and must take into consideration the assumptions made for pricing the contracts.

- The amount of the liability must be equal to the amount of the liabilities to policyholders, that is,

- the present value of the net expected future cash flows; and

- an allowance for inherent risk and uncertainty, that is, a margin for risk.

In addition to the liabilities to policyholders, a margin would be recorded as a liability in order to recognize the profit over the term of the contracts, consistent with the principle above.

- The present value of the net expected future cash flows must be determined on the basis of the management's best estimates

\footnotetext{
${ }^{5}$ The Chief Risk Officer Forum (CRO Forum) comprises risk officers of the major European insurance companies and financial conglomerates, and was formed to address the key relevant risk issues. It is a professional group focused on developing and promoting industry best practices in risk management. The membership comprises: Aegon, Allianz, Aviva, AXA, Converium, Fortis, Generali, ING, Munich Re, Prudential, Swiss Re, Winterthur and Zurich Financial Services.
} 
- without unbundling of the financial and non financial components;

- on a portfolio basis;

- reflecting policy behaviour for options, lapses and renewals (i.e., the recurring premiums);

- without deposit floor.

- The allowance for inherent risk and uncertainty shall be determined by the management in a manner that reflects the characteristics of the expected future cash flows. It includes the profit that would be required in a transfer of portfolio of contracts to another insurer (i.e., "wholesale profit" in a business-to-business transaction).

- The profit margin corresponds to the profit that the insurer acquires when delivering its service to the policyholders (i.e., "retail profit" in a business-to-customer transaction).

- A customer intangible asset (CIA) must be recognized:

- it represents the access to future benefits obtained from a portfolio of contracts as a result of establishing the customer relationship;

- the best proxy for the value of the customer intangible asset at inception is the initial acquisition costs arising from the contract;

- initial acquisition costs represent all costs associated with procuring the insurance contract, including direct and indirect marketing and sales costs, and related overheads.

The measurement must be "market consistent"; that means that the market data should be taken into consideration rather than the entity specific data:

- The management's best estimates are based on available market information.

- The cash flows shall be discounted at the risk-free rate:

- the valuation of insurance liabilities has to be independent of the assets backing contracts (except if insurance liabilities are linked to value of assets);

- the discount rate is consistent with the pricing of contracts (as for the $\mathrm{EEV}^{6}$ );

- it is a risk-free rate appropriate to the liabilities (i.e., may include liquidity premium).

- Options and guarantees must be taken into account:

- the inclusion of all options and guarantees is necessary to reflect the economic reality of the business being written and to be consistent with the management of the business;

- the insurance liability shall include both the intrinsic value and the time value of all options.

- The assumptions must be unlocked:

- the financial assumptions (discount rates...): at each reporting period end (as for assets which are valued at fair value);

- the non-financial assumptions (mortality tables...): if sustainable changes.

- The credit standing of the insurance entity does not affect the amount of the liabilities.

${ }^{6} \mathrm{EEV}$ : European Embedded Value. This is the standard developed by the CFO Forum and published in May 2004 to foster convergence and homogeneity in the way European insurance companies publish embedded value information for their life insurance contracts. 
The insurer holds assets backing its insurance liabilities:

- Investments and liabilities shall be consistently accounted for: changes due to financial factors impacting both assets and liabilities must be reflected in a consistent manner in the financial statements (either in the income statement or through equity).

The above principles shall be applied to the insurance contracts. The same principles shall be applied to participating contracts taking into consideration the specific features of those contracts:

- Participating contracts are insurance and investment contracts with discretionary participation features as defined in IFRS 4, and also other insurance and investment contracts that contain benefits that are under the discretion of management. The discretionary amounts may relate to either the amount or timing of the cash flows or both.

- The insurance liability should include all anticipated future payments to policyholders. This would be based on an economic approach and include guaranteed benefits and expected future additional benefits.

Other value-based information such as EEV for life and saving products would be disclosed as complementary information.

\section{Implications of the CFO Forum elaborated principles}

\section{Positive impact for users...}

The CFO Forum proposals constitute a real attempt to respond to the needs of users of financial statements. Investors, shareholders and other users of our financial statements need to have an optimal understanding of the insurance company's accounts.

The CFO Forum proposals are not a lobbying position to suit the wishes of the insurers but aim to provide users with transparent, harmonized and comparable financial information in a cohesive and comprehensive way, reflecting the nature of business and how it is managed. They are consistent with EEV already published by the CFO Forum members. For these reasons, the proposed principles better meet the needs of users than some of the IASB proposals. Moreover, they should enhance the insurance activity by decreasing the cost of the financing for insurers, increasing the insurance contracts supply and allowing for a more efficient capital allocation and greater cross-border investment. Until now, in the absence of a final standard, the insurance industry is one of the few industries still applying a patchwork of different and unsatisfactory accounting principles. These result in financial statements that are a hindrance rather than a help to comparing financial positions with companies in other sectors and even between insurers. Limiting insurers' ability to compete, and requiring them to pay a higher price for capital than would be the case with better financial reporting, ultimately penalizes consumers because it negatively affects the range of products offered and premiums they pay. 


\section{But huge operational implications}

The application of the CFO Forum principles will entail very significant impacts on the various operational fields:

- Product pricing will be impacted by the "market consistent" view of investment margins. As an example, most fixed annuity contracts currently sold would produce a loss at inception.

- IT systems and process/auditing will have to be adapted and upgraded in order to permit reporting based on current estimates of future cash flows.

- ALM and investment impacts on new base.

- P\&C should be likely less impacted than life but systematic discounting of claims reserves will be a significant new development (claims development triangle will have to be modified).

There are still several open issues such as:

- Sensitive disclosures issues including notably future expected policyholder bonuses and product profit margin.

- Expense analysis to be required (treatment of overhead expenses, what is in the CIA asset limit, etc.).

\section{What shall we look for?}

Main topics in debate for accounting and financial reporting

Among the various topics under discussion with the IASB and between insurers, there are several crucial topics.

\section{One single model}

The IASB and the CFO Forum propose one single model for life and non-life insurance. The GNAIE considers that there are fundamental differences between non-life and life contracts that render the application of one uniform accounting model to both types of contracts inappropriate:

- more uncertainty for non-life both related to the timing and the settlement amount of loss payments;

- on an aggregate book of business, the level of uncertainty in timing of payments to policyholders is greater for non-life than some life contracts.

\section{Non-life insurance}

Given the greater uncertainty of both the amount and timing of payments for non-life relative to most life contracts, the GNAIE believes that discounting and setting up an explicit risk margin add additional complexity and would be based on variable estimates which would be inherently less reliably for non-life.

For pre-claims reserves, could the "unearned premium approach" be used as a proxy for the prospective valuation in certain circumstances? 


\section{Market consistency if no market}

The proposals from the CFO Forum as well as the IASB orientations are based on a market consistent approach that requires referring to market data. Indeed, there is no direct market data for insurance contracts since they are not traded in a real market. Transactions between insurers and re-insurers do not constitute a market. The same issue has been considered for the EEV.

\section{Discount rate}

The European insurers propose to use a risk-free rate of return specific to the liabilities being measured. For instance, annuities do not carry liquidity risks and should be discounted at a rate including a liquidity risk premium. The IASB orientations seem to support a similar approach.

The American and Japanese insurers consider that the life insurance liabilities should be discounted at projected earnings rates depending on the investment strategy of the insurer since their contracts are priced on this basis. But this approach is not market consistent.

\section{Disclosure of margin}

According to the various propositions, the amount of insurance liabilities should include margins for risk and profit. Should these margins and/or split of them be disclosed? Publicly or only for certain stakeholders such as supervisors? If there is a Liability Adequacy Test as proposed by European insurers, should the amount calculated in the test be disclosed? On an aggregate or detailed basis?

There are arguments in favour of and against such (public) disclosures:

- benefits might be eliminating excessive prudence in Solvency capital and reserves and ensuring profit margin can be used for available capital, some convergence in assumptions ensuring similar products are treated consistently across firms, greater transparency;

- against this, the drawbacks of disclosing could be volatility in $\mathrm{P} / \mathrm{L}$, impact on competitive situation due to disclosure of confidential information.

\section{Portfolio basis}

All the insurers consider that the measurement of liabilities must be based on a portfolio basis consistent with how the business is managed. The IASB has considered that the portfolio should be the basis for measuring the risk margin but not for valuing the expected future cash flows themselves.

Beyond the impact of the mutualization to be taken into account, there are questions about the benefit of diversification linked to Solvency:

- portfolios level and group level: decrease of risk margin in liabilities and decrease of Solvency capital requirement;

- how to manage cross-border capital support that would allow diversification at the group level.

\section{Customer intangible asset (CIA)}

The IASB, while recognizing it is an asset, would book the CIA as a deduction to the liabilities (net presentation). 
The CFO Forum believes that the CIA should be recognized on the asset side of the balance sheet (gross presentation), because such presentation provides more relevant information.

Should the CIA be limited to acquisition costs? And if so what acquisition costs? The CFO Forum proposes to include all acquisition costs, including associated costs, direct and indirect.

\section{Changes in value of assets and liabilities through $P \& L$ or through equity}

Changes of fair value of financial assets are recognized either directly in the income statement or through equity depending on the classification of assets under current IAS. The changes in the value of the insurance liabilities should be recognized in a consistent way through the income statement or equity. Except in specific cases (pensions) the IASB has forever rejected allowing recognition of changes in liabilities through equity.

\section{Participating contracts}

Insurers as well as supervisors (cf., IAIS second set of observations on Phase II project, May 2006) support an economic approach where the expected future discretionary bonuses must be recognized as a liability. The IASB would adopt a strict legal approach considering this not a liability as long as the insurer is not committed to an unconditional obligation to pay.

This issue is a very critical issue since the IASB position would lead to recognizing in equity huge amounts that in fact will be distributed to the policyholders.

\section{Reconciliation between Solvency II and IFRS Phase II}

The European Commission has launched its Solvency II project for the revision of the regulation and supervision of the European insurance companies. The tentative deadline is 2009 for the application of the Directive compared with 2010 for the expected first application of IFRS (see appendix). The Solvency II project is based on three pillars; pillar 1 addresses the measurement of insurance liabilities, which should be based on the measurement of the liabilities under IFRS.

As mentioned above, CEA and CRO Forum have made proposals for measurement of liabilities for solvency purposes. Those proposals and the proposals for accounting purpose made by the CFO Forum with the support of the CEA are based on the same liabilities to policyholders measurement and so are fully reconcilable.

\section{Two different points of focus}

For Solvency, the amount of liabilities should be based only on an economic approach. No prudence is included on top of the market value of liabilities to cover the risk that the actual values over time vary from the current market value estimates. It is the purpose of the solvency capital requirement to cover this risk.

For accounting purposes, an insurer's performance is reported when the service has been provided to policyholders:

- profits are recognized with release from risk;

- liabilities are topped by margin for future profits. 


\section{At two different levels}

The CRO Forum proposals are technical: market cost of capital approach to market value margins. The CFO Forum's "Elaborated Principles" are high-level businessbased principles without at this stage guidance on techniques to be used. However the CFO Forum strongly supports the cost of capital as the preferred technique for valuing the risk margin.

\section{But articulated in one coherent framework}

The basis for the proposals for solvency and for accounting purposes are the same:

- market consistent liabilities measurement;

- BEL and risk margin (see Figure 2).

Next steps...

Acceptance from the IASB, the supervisors and the EC of this overall framework and the two different points of focus (Solvency, Accounting) is key. That requires:

- a coherent terminology for Accounts and Solvency II: same concepts and same definitions,

- to show that the approaches are not only reconcilable but reconciled;

- to complete the reflection on the disclosures of margins (see above).

The industry is still debating whether one single set of accounts or two separate sets should be required. The debate is influenced by the different experiences:

- for the European industry: the current regulation is based on one set of accounts for accounting and for solvency with "prudential adjustments/filters";

- for the U.S. insurers: the supervision is based on a separate set of accounts.

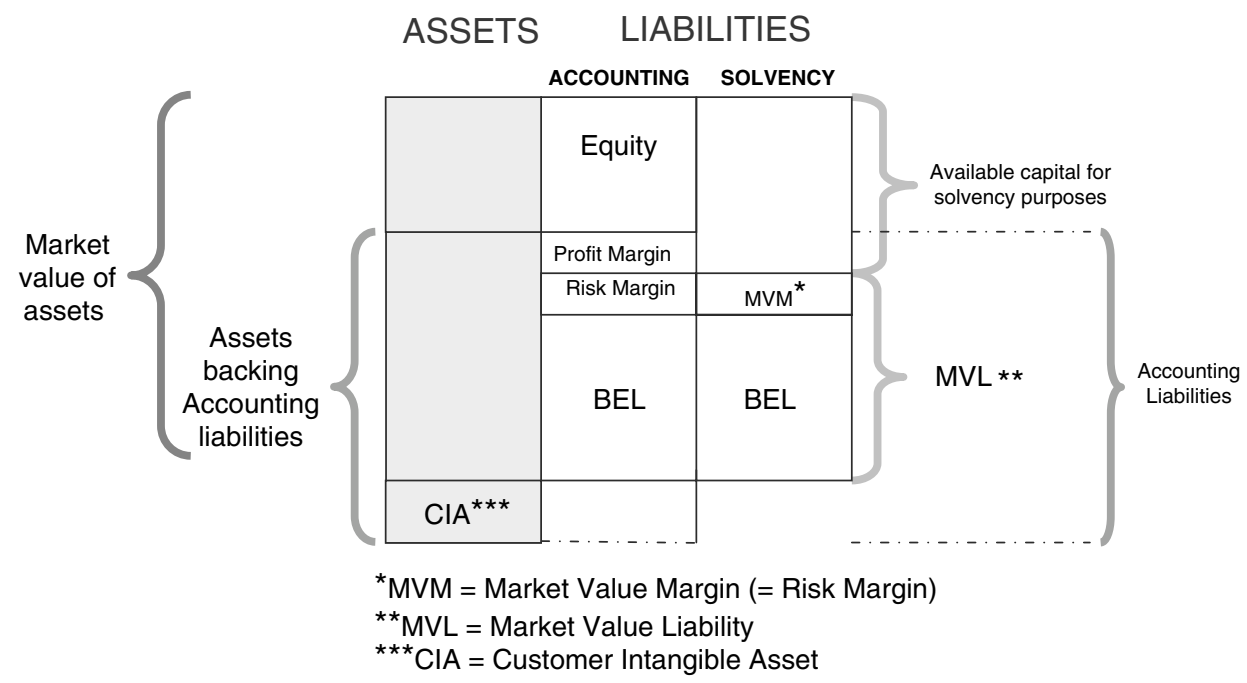

Figure 2. Assets and liabilities for solvency and accounting. 
However, the debate could be settled by the supervisors; at the international and European levels, the supervisors (IAIS, including NAIC representatives and CEIOPS) appear to adopt similar positions on liabilities measurement which are close to the IASB orientations for a prospective current value.

\section{Conclusion}

The insurance industry remains handicapped as it is the only industry that lives with a temporary flawed accounting standard, IFRS 4 . This has an economic cost to the industry and to its customers: a higher cost of capital because of a lack of relevance of the standard.

As the IASB prepares Phase II for insurance contracts while at the same time the EU prepares Solvency II, a new solvency regime that should rely on IFRS accounts, the odds for the industry are very high.

After the failure of Phase I, the industry seems determined to speak with one voice. This is already the case in Europe with the high level of coordination that has been developed between CEA, CFO Forum and CRO Forum. The distance between European insurers and their U.S. and Japanese colleagues is diminishing fast. Getting to a single position is critical at this juncture. And The Geneva Association should be able to facilitate this convergence.

\section{Appendix}

IFRS Phase II and Solvency II timetable

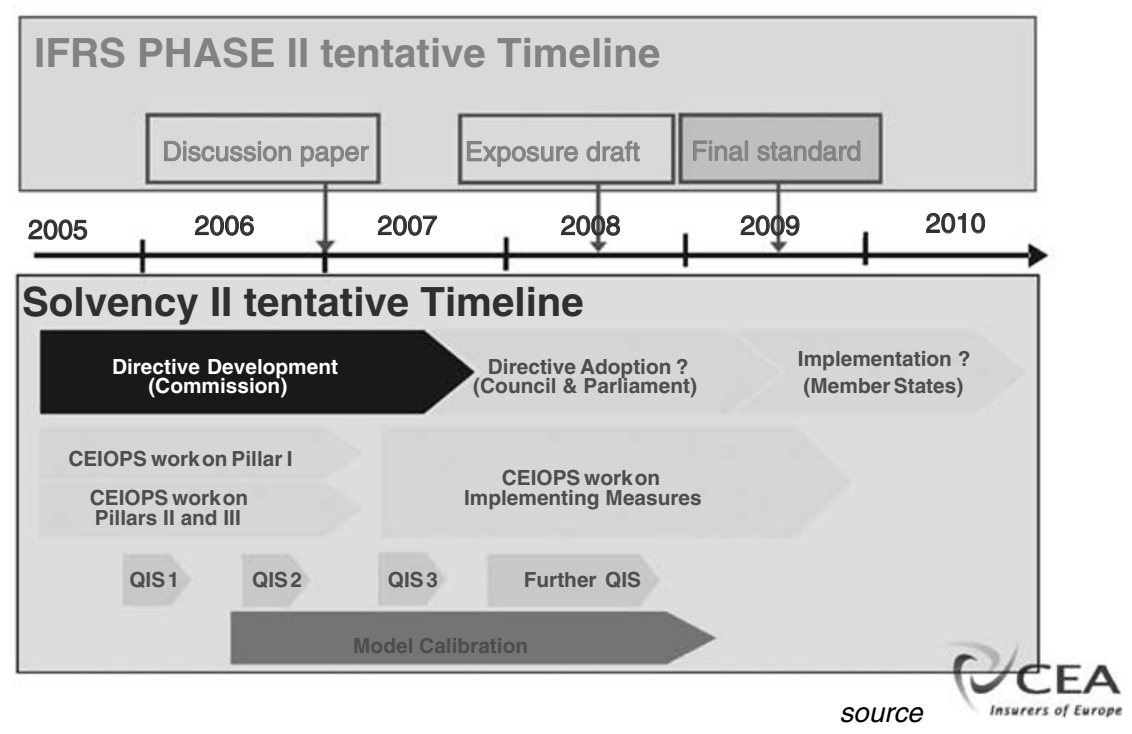




\section{About the Authors}

Denis Duverne is Chief Financial Officer of AXA Group - Finance, Control and Strategy. He graduated from HEC Business School and from the Ecole Nationale d'Administration. He joined AXA in 1995 and its Executive Committee in January 2000, as Executive Vice President, Finance, Control and Strategy. Since February 2003, he is a member of the Management Board of AXA, in charge of Finance, Control and Strategy.

Jacques Le Douit is a senior manager for accounting research and development, in AXA. Before joining AXA in 1997, he was responsible for Accounting and Consolidation Department of UAP. He is a member of the French Standard-Setter "Conseil National de la Comptabilité" (CNC) as representative of Insurance enterprises and the chairman of the $\mathrm{CNC}$ Insurance committee since its creation in 1996. He is Chairman of the Accounting committee of the French insurance association (FFSA), Chairman of the Accounts committee of the "Comite européen des assurances" (CEA) and a member of the EFRAG Insurance Accounting Working Group (previously Insurance Sub Committee). He used to be a member of the Insurance Steering committee of the IASC. He is Paris Dauphine University graduate with a Master degree in Management, Accountancy and Finance and DECS (Diplôme d'Etudes Comptables Supérieures). 